\title{
Germination of Thermoactinomyces vulgaris Endospores: Microscopic and Optical Density Studies Showing the Influences of Germinants, Heat Treatment, Strain Differences and Antibiotics
}

\author{
By R. W. AT'TWELL AND T. CROSS \\ Postgraduate School of Studies in Biological Sciences, University of Bradford, \\ Bradford, Yorkshire, $B D 7$ I $D P$ \\ AND G. W. GOULD \\ Unilever Research, Colworth/Welwyn Laboratory, Colworth House, \\ Sharnbrook, Bedford
}

(Received 6 March 1972; revised 7 June 1972)

SUMMARY

Germination of the endospores of the thermophilic actinomycete Thermoactinomyces vulgaris (isolate CUB337) was observed by means of phase-contrast and electron microscopy. The first cytological change was the appearance of four fibrillar regions in the core. During germination the core became granular in texture and swollen, the cortex became laminated and later uniformly reduced to a thin layer. At this late stage of germination and before outgrowth, layers external to the cortex also showed signs of breakdown. The endospores were induced to germinate by $10 \mathrm{~mm}$ solutions of L-leucine, $\mathrm{L}-\beta$-phenylalanine, $\mathrm{L}$-alanine, $\mathrm{L}$ - $\alpha$-amino butyric acid, L-valine, L-methionine, $\mathrm{L}$-cystine, $\mathrm{L}-\beta$-asparagine, inosine, adenosine and by I mM- $N$-dodecylamine. The effect of heat treatment in general decreased germination but a period of storage increased germination. Outgrowth was inhibited by nisin but was less sensitive to novobiocin than was outgrowth in Bacillus coagulans.

The response of isolate CUB337 to germinant compounds resembled that of Bacillus cereus but when endospores of nine other Thermoactinomyces vulgaris isolates were tested, considerable strain variation was observed.

\section{INTRODUCTION}

Endospores produced by bacteria classified in the genera Bacillus and Clostridium have been intensively studied for many years because of their importance in commercial and medical fields (Gould \& Hurst, 1969). Detailed studies have been limited to a few strains capable of producing high yields of spores which can be harvested and purified easily.

Most genera of spore-forming bacteria and the greatest variety of spore types are found in the Actinomycetales (Cross, 1970). Studies of actinomycete spores may contribute to our understanding of the properties of spores in general. As part of such a study, certain aspects of endospore germination in the species Thermoactinomyces vulgaris have been investigated.

Thermoactinomyces vulgaris is a thermophilic actinomycete which produces many single sessile spores along the entire length of its hyphae. The spores are considered true bacterial endospores since they are formed endogenously, have a typical endospore fine structure, are heat resistant $\left(D_{100}{ }^{\circ} \mathrm{C}=\right.$ I I min), highly refractile, contain dipicolinic acid and do not 
take up simple stains (Cross, Walker \& Gould, 1968). Changes taking place in the endospores of $T$. vulgaris strain CUB337 during germination and before outgrowth were observed by using phase-contrast and electron microscopy. The response of several strains to germination systems found effective for other bacterial endospores was measured by observing changes in optical density (o.D.).

\section{METHODS}

Organisms. The Thermoactinomyces vulgaris strains were isolated by using the selective medium containing novobiocin and cycloheximide of Cross (1968) from various hay, soil, lake mud and leaf-litter samples. Strain CUB6I5 (I227) was isolated by Professor D. A. Hopwood, John Innes Research Institute, Norwich, and used together with CUB76 in genetic studies (Hopwood \& Ferguson, I970). The Bacillus coagulans strain used was NCTC 399 I (Gould, Jones \& Wrighton, I968).

Production of endospores. The sporulation medium contained (g/l distilled water): Czapek Dox Agar granules (Oxoid), 45.4; Yeast Extract (Oxoid), 2.0; Vitamin-Free Casamino Acids (Difco), 6.0; $\mathrm{pH} 77^{\circ}$. Thermoactinomyces vulgaris was grown on $70 \mathrm{ml}$ of this medium in a $250 \mathrm{ml}$ conical flask incubated for $72 \mathrm{~h}$ in a humidified incubator at $50{ }^{\circ} \mathrm{C}$. Spores and hyphal fragments were removed from the surface of the cultures by using sterile glass beads and distilled water. The suspension was filtered through glass wool and Whatman no. I filter paper to remove hyphal debris, then washed five times in cold distilled water by centrifugation. Suspensions of approximately $2 \times 10^{10}$ phase-bright spores $/ \mathrm{ml}$ in distilled water were stored at $4{ }^{\circ} \mathrm{C}$. Where indicated, the suspensions were heated for $\mathrm{I} 5 \mathrm{~min}$ at $90^{\circ} \mathrm{C}$ before use, and were always used within $\mathrm{I} h$ after this treatment.

Bacillus coagulans spores were produced and cleaned as described by Gould et al. (I968). They were heat-activated at $70^{\circ} \mathrm{C}$ for $30 \mathrm{~min}$ before use.

Germinants, antibiotics and buffers. L- $\alpha$-Amino- $n$-butyric acid and purine ribosides were obtained from Sigma Biochemicals (London) Ltd. L-Alanine, L-asparagine and L-cysteine were obtained from Koch-Light Ltd, Colnbrook, Buckinghamshire; L-valine, L-proline and L-leucine from Hopkin \& Williams, Chadwell Heath, Essex. Other amino acids, sugars, $\mathrm{N}$-dodecylamine, sodium lactate and inorganic chemicals were from British Drug Houses Ltd, Poole, Dorset. Nisin was supplied by Aplin and Barrett Ltd, Yeovil, Somerset, as Nisaplin, activity $\mathrm{I} \times \mathrm{IO}^{6}$ Reading units $(\mathrm{RU}) / \mathrm{g}$. Novobiocin was obtained from Upjohn Ltd, Crawley, Sussex. Sodium phosphate buffer, $0.05 \mathrm{M}\left(\mathrm{pH}\right.$ 7) was prepared from $\mathrm{NaH}_{2} \mathrm{PO}_{4}$ and $\mathrm{Na}_{2} \mathrm{HPO}_{4}$ and tris buffer, $0.075 \mathrm{M}(\mathrm{pH} \mathrm{8})$ from tris (hydroxymethyl) methylamine and $\mathrm{HCl}$. Nutrient broth used at half strength as a germination system contained $(\mathrm{g} / \mathrm{l}$ distilled water): Bacteriological Peptone (Evans Medical, Runcorn, Cheshire), 5.0; 'Lab-Lemco' (Oxoid), 5.0; and sodium chloride, $5 \cdot 0 ; \mathrm{pH} 7 \cdot 2$.

Phase-contrast microscopy. A sterile agar square cut from a thin layer of half strength nutrient agar (g/l: Nutrient Broth granules (Oxoid, CMI), 6.5; agar, I0.0) was transferred to a sterile microscope slide. The agar surface was lightly inoculated with spores of CUB337, covered with a cover-glass and incubated at $50^{\circ} \mathrm{C}$ in a Petri dish containing damp filter paper. Selected spores were examined at intervals by means of phase-contrast optics.

Electron microscopy. One $\mathrm{ml}$ samples were taken at intervals from a suspension of spores $\left(\mathrm{I} \times \mathrm{IO}^{8} / \mathrm{ml}\right)$ of isolate CUB337 incubated in nutrient broth at $50^{\circ} \mathrm{C}$. Each sample was cooled in ice before the spores were centrifuged and fixed by suspending in $\mathrm{Io} \mathrm{ml}$ of freshly filtered $2 \%(\mathrm{w} / \mathrm{v}) \mathrm{KMnO}_{4}$ solution and left for $90 \mathrm{~min}$ at $22{ }^{\circ} \mathrm{C}$ (Mollenhauer, 1959). The fixed material was then washed twelve times by suspension in cold distilled water and centrifugation. Another set of samples was fixed in $5 \%(\mathrm{w} / \mathrm{v})$ glutaraldehyde in $0 . \mathrm{I} \mathrm{M}$-phosphate buffer 
( $\mathrm{pH} 7 \cdot 3$ ) for $90 \mathrm{~min}$ at $4{ }^{\circ} \mathrm{C}$. The spores were then washed once in cold buffer, suspended in $\mathrm{I} \%(\mathrm{w} / \mathrm{v}) \mathrm{OsO}_{4}$ solution for $\mathrm{I} 20 \mathrm{~min}$ at $4{ }^{\circ} \mathrm{C}$, and washed four times by suspension and centrifugation in cold distilled water (Hamilton \& Stubbs, 1967). Spores fixed by either method were embedded, sectioned, and then examined in a J.E.M. 7 A electron microscope.

Measurement of germination. Germination experiments were started by adding spores to particular germinant systems held at $50{ }^{\circ} \mathrm{C}$ and followed at regular intervals by means of a Biochem absorptiometer (Hilger \& Watts Ltd, Campden Road, London) with a $580 \mathrm{~nm}$ peak-transmission filter. Germination was usually maximal after $30 \mathrm{~min}$ and suitable systems supported outgrowth after $60 \mathrm{~min}$ so the two times were chosen to illustrate the effects of germinants (Tables $r$ to 3 ). Some strains exhibited very rapid outgrowth in nutrient broth and the minimum optical density was recorded before 30 min incubation. Germination and outgrowth were verified by using phase-contrast microscopy.

\section{RESULTS}

Phase-contrast microscopy. Dormant spores of Thermoactinomyces vulgaris were phasebright and averaged $0.82 \mu \mathrm{m}$ in diameter (Fig. I $a$ ). After incubation for $60 \mathrm{~min}$ at $50^{\circ} \mathrm{C}$ on half strength nutrient agar, most of them had become phase-dark and were enlarged in diameter to about $\mathrm{I} \cdot \mathrm{I} \mu \mathrm{m}$ (Fig. $\mathrm{I} c$ ). Spores undergoing darkening but not fully phase-dark were occasionally seen (Fig. I $b$ ).

Electron microscopy. In contrast to the $\mathrm{KMnO}_{4}$-fixed spores, those fixed in glutaraldehyde and $\mathrm{OsO}_{4}$ showed more detail in the cortex and coat layers (Fig. I $d-g$ ). Initially they had a clearly defined cortex and core membrane. Early in germination the cortex became more conspicuous and laminated, the core appeared granular and the inner coat was frequently broken, the gaps interrupting its typical laminated appearance. In the germinated spore the cortex was reduced to a thin layer surrounding the swollen core and the coat layers showed signs of destruction.

The dormant endospores fixed with $\mathrm{KMnO}_{4}$ had a thin outer coat of constant thickness and a ridged intermediate one surrounding an inner multilayered coat (Fig. 2). These integuments enclosed a dark diffuse layer outside the wide electron-transparent cortex which in turn surrounded an electron-dense core bounded by a plasma membrane.

This fixation method revealed a very early stage in germination, namely the appearance of four electron-transparent areas in the core. These areas developed a fibrillar structure resembling nuclear material, appeared to coalesce, and eventually occupied the central part of the core which developed a fine granular texture. During germination the spores became swollen and showed an enlarged granular core, with a localized fibrillar network and a well-defined boundary membrane. The cortex became thinner and appeared more electron-dense, and the breakdown of intermediate and outer coats was evident.

Germination agents for spores of various Thermoactinomyces vulgaris strains. Table I shows the compounds which were tested for inducing germination of isolate CUB337 endospores. A compound was regarded as germinative if the extent of germination (i.e. fall in o.D. during an incubation period of $60 \mathrm{~min}$ ) was greater in its presence in the control system than in its absence. Results obtained with unheated and heat-treated spores were compared and in all treatments, except with $\mathrm{N}$-dodecylamine, the prior heat treatment reduced the rate and extent of germination.

Table 2 gives results obtained with endospores of isolate CUB337 and those of nine other strains. The responses of spores to two germinant systems and a control were examined within $24 \mathrm{~h}$ of their collection from agar cultures. Heat-treated spores of most strains ger- 

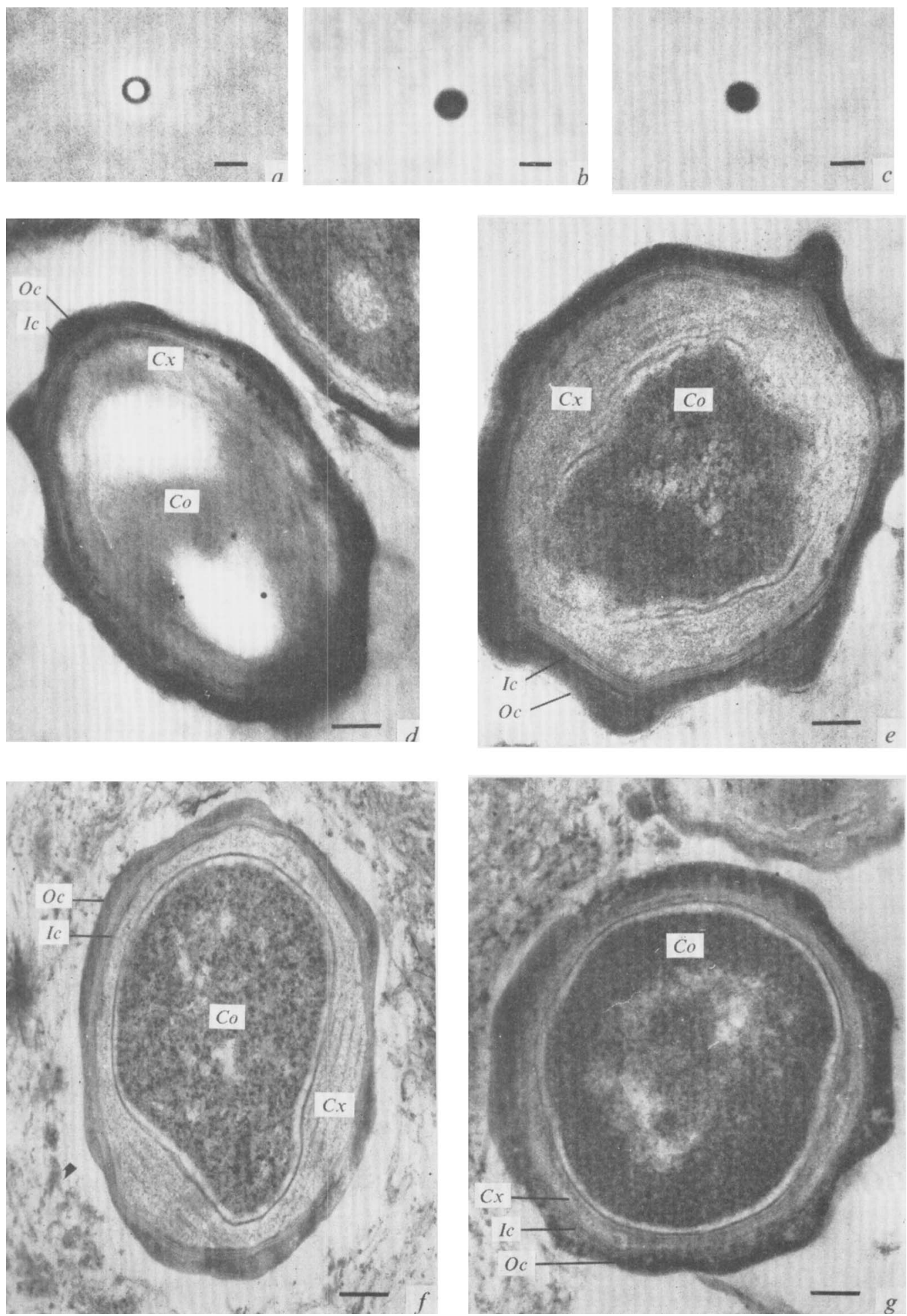
Table I. Germination of endospores of Thermoactinomyces vulgaris CUB337 in a range of germinant systems

Each germinant compound except $N$-dodecylamine was used at Io mM concentration in tris buffer, $0.075 \mathrm{M}(\mathrm{pH} 8)$. N-Dodecylamine was used at I mM concentration in sodium phosphate buffer, $0.05 \mathrm{M}(\mathrm{pH} 7.0)$. Germination was measured by fall in o.D. of the spore suspension in each germinant system during incubation at $50{ }^{\circ} \mathrm{C}$.

Fall in o.D. after incubation of spore suspensions for 30 and $60 \mathrm{~min}(\%)$

Germinant compound

Control (no germinant added)

L-Leucine

L- $\beta$-Phenylalanine

L-Alanine

L- $\alpha$-Aminobutyric acid

L-Valine

L-Methionine

L-Cysteine

L- $\beta$-Asparagine

Inosine

Adenosine

Inosine + L-alanine, $10 \mathrm{~mm}$

Adenosine $+\mathrm{L}$-alanine, $10 \mathrm{~mm}$

Xanthosine $+\mathrm{L}$-alanine, $10 \mathrm{~mm}$

reatment

$\frac{\text { No heat treatment }}{30 \mathrm{~min}}$

$N$-Dodecylamine

$\mathrm{KCl}$

$\mathrm{KNO}_{3}$

$\mathrm{NaCl}$

$\mathrm{NaNO}_{3}$

$\begin{array}{rr}4 & 6 \\ 39 & 45 \\ 29 & 36 \\ 3 \text { I } & 34 \\ 27 & 33 \\ 21 & 3 \text { I } \\ \text { II } & 23 \\ 8 & \text { II } \\ 5 & 7 \\ 32 & 34 \\ 24 & 3 \text { I } \\ 32 & 37 \\ 36 & 37 \\ 24 & 32 \\ \text { I I } & 24 \\ 4 & 7 \\ 4 & 6 \\ 7 & \text { I } 3 \\ 6 & \text { IO }\end{array}$

$\overbrace{30 \mathrm{~min}}^{\text {Heat treated } *}$

33

$3 \mathrm{I}$

23

II

7

34

3I

37

37

32

24

7

I 3

NT

$\begin{array}{rr}2 & 2 \\ 26 & 34 \\ 8 & 18 \\ 2 & 7 \\ 3 & 6 \\ 1 & 7 \\ 1 & 4 \\ 2 & 4 \\ 0 & 0 \\ \text { I } 4 & 20 \\ \text { NT } & \text { NT } \\ 27 & 30 \\ \text { NT } & \text { NT } \\ \text { NT } & \text { NT } \\ \text { I5 } & 30 \\ \text { NT } & \text { NT } \\ \text { NT } & \text { NT } \\ \text { NT } & \text { NT } \\ \text { NT } & \text { NT }\end{array}$

* Spores were heat treated at $90^{\circ} \mathrm{C}$ for $15 \mathrm{~min}$ in water. NT $=$ not tested.

The following compounds were also tested individually at $10 \mathrm{~mm}$ concentration and found to be inactive: L-threonine, L-glutamate, L-lysine, L-proline, L-arginine, xanthosine, D-glucose, D-fructose, D-glucosamine and sodium lactate.

minated more slowly than unheated spores; strains CUB428 and s 3 were exceptions in that their germination in half-strength nutrient broth was enhanced by prior heat treatment.

Results given in Table 3 were obtained with spores stored for Io days at $4{ }^{\circ} \mathrm{C}$ after their collection from the culture. The period of storage resulted in an increase in the germination of most strains.

Tables 2 and 3 demonstrate a considerable strain variation in response to germinants by spores of Thermoactinomyces vulgaris. Strains such as CUB296 and R I showed little germination in any of the systems used except $N$-dodecylamine. Conversely, CUB $76 \mathrm{H}$ was induced to germinate by most of the systems tested. Half-strength nutrient broth induced all strains

Fig. I. (a) to (c). Phase-contrast photomicrographs of Thermoactinomyces vulgaris endospores. Bar marker represents $\mathrm{I} \mu \mathrm{m}$. (a) Dormant phase-bright spore. (b) Germinating phase-darkening spore. (c) Germinated phase-dark spore. $(d)$ to $(g)$ Electron micrographs of thin sections of glutaraldehyde $+\mathrm{OsO}_{4}$ fixed endospores of Thermoactinomyces vulgaris isolate cuB337. Abbreviations used: $C o=$ core, $C x=$ cortex, $I c=$ inner coat, $O c=$ outer coat. Bar markers represent $0 \cdot 1 \mu \mathrm{m} .(d)$ Dormant endospore. (e) Early stage in germination showing thick cortex. $(f)$ Germinating endospore with laminated cortex and gaps in inner coat. The granular core is surrounded by a distinct membrane. $(g)$ Germinated endospore showing swollen core, thin cortex and beginning of coat-layer destruction. 

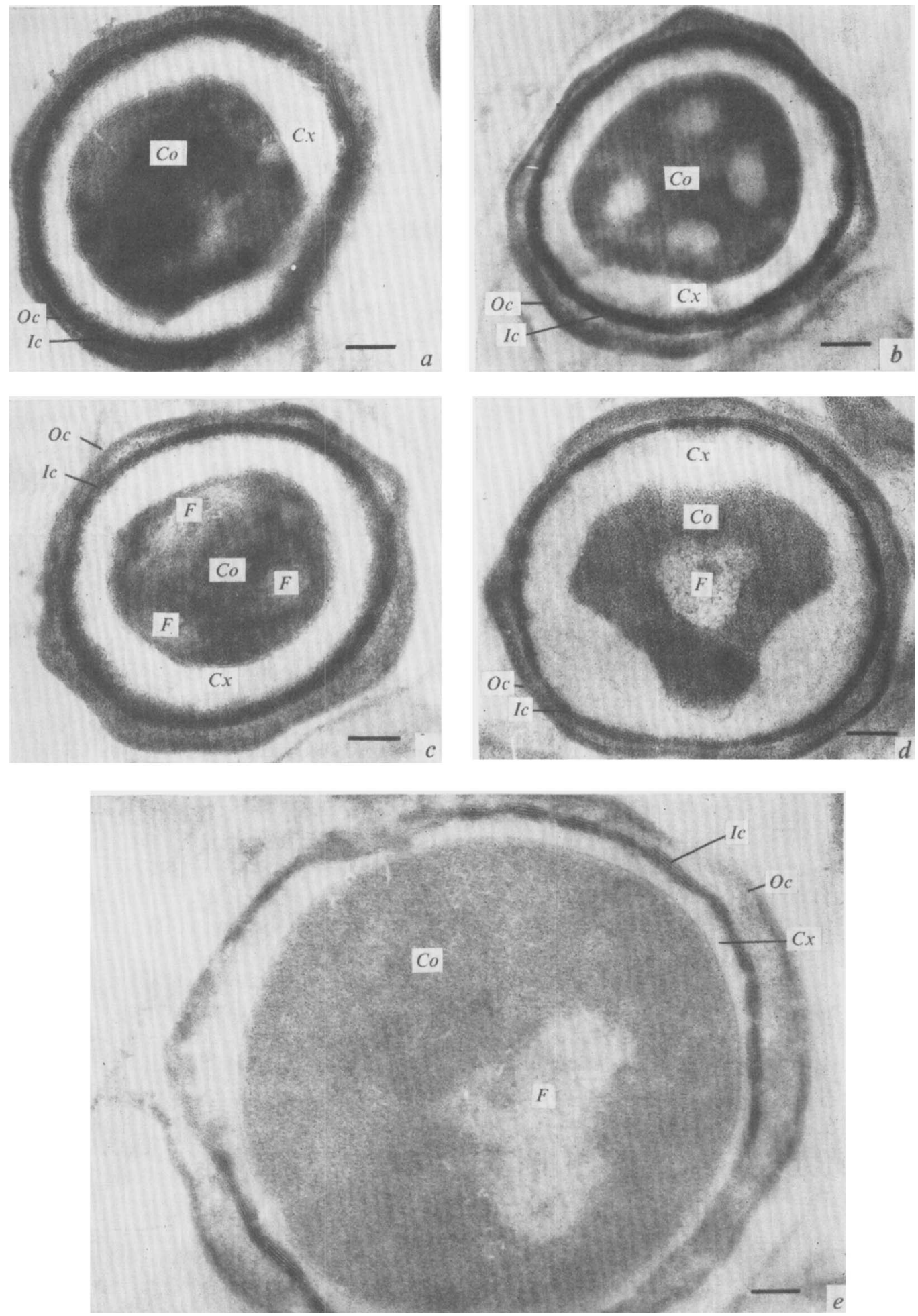
Table 2. Germination of endospores of Thermoactinomyces vulgaris strains in selected germinant systems 24 h after harvest

L-Alanine was used at $10 \mathrm{~mm}$ concentration in tris buffer, $0.075 \mathrm{M}(\mathrm{pH} 8)$. Germination was measured by fall in O.D. of the spore suspension in each germinant system during incubation at $50{ }^{\circ} \mathrm{C}$.

\begin{tabular}{|c|c|c|c|c|c|c|c|c|c|c|}
\hline \multirow{4}{*}{$\begin{array}{c}\text { Incubation time } \\
\text { (min) } \ldots\end{array}$} & \multicolumn{10}{|c|}{ Fall in O.D. after incubation of spore suspensions for 30 and $60 \mathrm{~min}(\%)$} \\
\hline & \multirow{2}{*}{\multicolumn{2}{|c|}{$\begin{array}{l}\text { Tris buffer, } \\
\text { control, } \\
\text { no heat } \\
\text { treatment }\end{array}$}} & \multicolumn{4}{|c|}{ L-Alanine } & \multicolumn{4}{|c|}{$\begin{array}{l}\text { Half-strength } \\
\text { nutrient broth }\end{array}$} \\
\hline & & & \multicolumn{2}{|c|}{$\begin{array}{l}\text { No heat } \\
\text { treatment }\end{array}$} & \multicolumn{2}{|c|}{$\begin{array}{l}\text { Heat } \\
\text { treated }\end{array}$} & \multicolumn{2}{|c|}{$\begin{array}{l}\text { No heat } \\
\text { treatment }\end{array}$} & \multicolumn{2}{|c|}{$\begin{array}{l}\text { Heat } \\
\text { treated }\end{array}$} \\
\hline & 30 & 60 & 30 & 60 & 30 & 60 & 30 & 60 & 30 & 60 \\
\hline CUB54 & 5 & 6 & 5 & 9 & 3 & I & 17 & 23 & 14 & I 8 \\
\hline CUB $76 \mathrm{H}$ & 2 & 3 & 15 & 20 & NT & NT & 19 & 19 & 3 & 7 \\
\hline CUB296 & I & 3 & 3 & 5 & 2 & 6 & 5 & 3 & 4 & 3 \\
\hline CUB337 & 4 & 6 & 4 & 6 & NT & NT & 8 & 2 & 0 & 7 \\
\hline CUB428 & 2 & 2 & 30 & 34 & 4 & 4 & 19 & 15 & 27 & 29 \\
\hline cuB6I5 & 5 & 5 & 24 & 28 & 5 & 5 & 33 & $2 \mathrm{I}$ & 27 & 26 \\
\hline RI & 3 & 3 & 4 & 4 & 4 & 6 & 8 & 9 & 8 & 9 \\
\hline $\mathrm{H} 2$ & 4 & 4 & 36 & 42 & I 8 & 24 & 13 & 13 & 3 & 6 \\
\hline S2 & o & 0 & I 6 & 26 & I & I & 12 & 9 & I & I \\
\hline s3 & 4 & 4 & 13 & 22 & 8 & 8 & I I & 9 & 31 & 32 \\
\hline
\end{tabular}

Figures in the 30 min column for half-strength nutrient broth are the lowest \% fall in o.D. recorded between $o$ and $60 \mathrm{~min}$ in that system and are not necessarily the reading at $30 \mathrm{~min}$. This figure is given since some strains show rapid outgrowth in nutrient broth causing an increase in o.D. after the initial decrease accompanying germination.

$\mathrm{NT}=$ not tested.

to germinate except CUB296, but prior heat treatment of spores increased germination in this medium of only $\mathrm{s} 3$ and to a limited extent CUB296. Most strains were induced to germinate by L-alanine and by inosine, although the level of response differed between strains. Glucose was ineffective for all strains and $\mathrm{KCl}$ and $\mathrm{NaCl}$ caused only slow germination of three of them. $N$-Dodecylamine caused germination of all Io strains.

Inhibition of outgrowth by the antibiotics nisin and novobiocin. Outgrowth, the emergence of a vegetative organism from a germinated spore, was observed as an increase in O.D. of a spore suspension. Such an increase in O.D. was evident for spores suspended in nutrient broth (Fig. $3 a, b$ ) after the initial drop in O.D. caused by germination. Nisin at concentrations of $\mathrm{I} \mu \mathrm{g} / \mathrm{ml}$ and above inhibited outgrowth in Thermoactinomyces vulgaris CUB337 (Fig. $3 a$ ). Novobiocin at $100 \mu \mathrm{g} / \mathrm{ml}$ also inhibited outgrowth of this organism, but outgrowth of Bacillus coagulans was inhibited by $25 \mu \mathrm{g} / \mathrm{ml}$ (Fig. $3 b$ ).

Fig. 2. Electron micrographs of thin sections of $\mathrm{KMnO}_{4}$-fixed endospores of Thermoactinomyces vulyaris isolate CUB337. Abbreviations used: $C o=$ core, $C x=$ cortex, $F=$ fibrillar material, $I c=$ inner coat, $O c=$ outer coat. Bar markers represent $0 . \mathrm{I} \mu \mathrm{m}$. (a) Dormant endospore. (b) Early stage in germination showing four electron-transparent regions in the core. (c) Germinating endospore showing fibrillar regions in the core. $(d)$ Germinating endospore showing single fibrillar region in the finely granular core. (e) Germinated endospore showing swollen core, thin cortex region and breakdown of coat layers. 


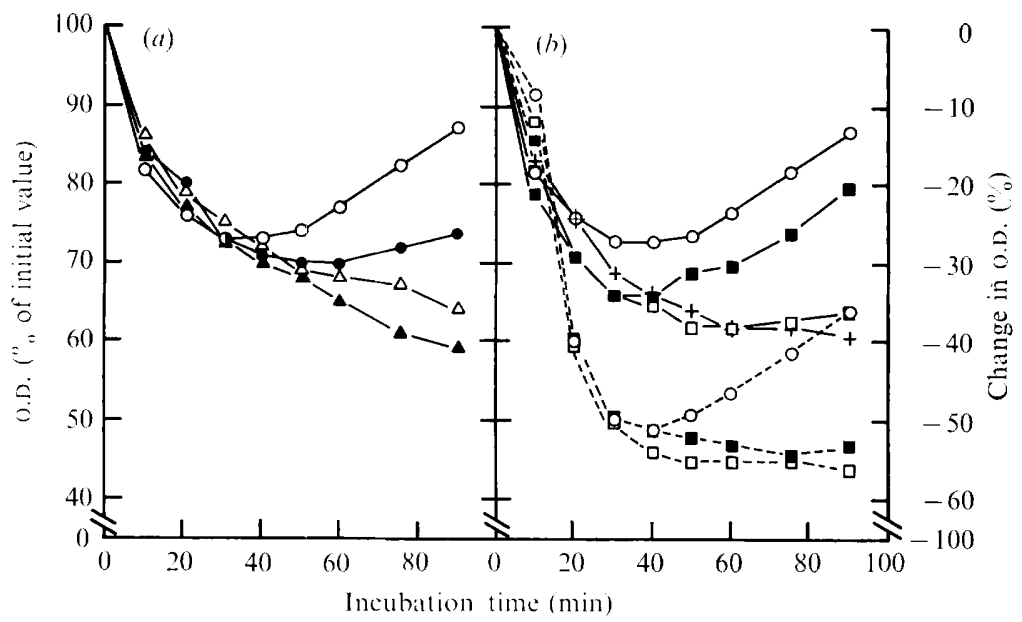

Fig. 3. (a) Effect of nisin on germination and outgrowth of Thermoactinomyces vulgaris CUB337 endospores in nutrient broth at $50^{\circ} \mathrm{C}(-)$. (b) Effect of novobiocin on germination and outgrowth of T. vulgaris CUB337 in nutrient broth at $50^{\circ} \mathrm{C}(-)$ and on germination and outgrowth of Bacillus coagulans NCTC 399 I endospores in nutrient broth $+\mathrm{L}$-alanine $(5 \mathrm{mM})$ at $37^{\circ} \mathrm{C}(--)$. Concentration of each antibiotic is indicated as follows: $O$, control without antibiotics; $\bullet$, nisin ( $\mu \mathrm{g} / \mathrm{ml})$; $\Delta, \operatorname{nisin}(\mathrm{ro} \mu \mathrm{g} / \mathrm{ml}) ; \Delta, \operatorname{nisin}(100 \mu \mathrm{g} / \mathrm{ml}) ; \mathbf{m}$, novobiocin $(25 \mu \mathrm{g} / \mathrm{ml}) ; \square$, novobiocin $(100 \mu \mathrm{g} / \mathrm{ml}) ;$ ,+ novobiocin $(200 \mu \mathrm{g} / \mathrm{ml})$.

\section{Table 3. Germination of endospores of Thermoactinomyces vulgaris strains in selected germinant systems io days after harvest}

Each germinant compound except $N$-dodecylamine was used at Io mM concentration in tris buffer, $0.075 \mathrm{M}$ (pH8). $\mathrm{N}$-Dodecylamine was used at I $\mathrm{mm}$ concentration in sodium phosphate buffer, $0.05 \mathrm{M}(\mathrm{pH} 7.0)$. Germination was measured by fall in o.D. of the spore suspension in each germinant system during incubation at $50^{\circ} \mathrm{C}$. Spores received no heat treatment except where indicated.

Fall in o.D. after incubation of spore suspensions for 30 and $60 \mathrm{~min}(\%)$

\begin{tabular}{|c|c|c|c|c|c|c|c|c|c|c|c|c|c|c|c|c|c|c|}
\hline \multirow[b]{2}{*}{ Time (min) } & \multicolumn{2}{|c|}{$\begin{array}{l}\text { Tris } \\
\text { buffer } \\
\text { control }\end{array}$} & \multicolumn{4}{|c|}{$\begin{array}{l}\text { Half-strength } \\
\text { nutrient broth }\end{array}$} & \multicolumn{2}{|c|}{$\overbrace{}^{\text {Alanine }}$} & \multicolumn{2}{|c|}{ Inosine } & \multicolumn{2}{|c|}{ Glucose } & \multicolumn{2}{|c|}{$\overbrace{}^{\mathrm{KCl}}$} & \multicolumn{2}{|c|}{$\overbrace{}^{\mathrm{NaCl}}$} & \multicolumn{2}{|c|}{$\begin{array}{c}N- \\
\text { Dodecyl- } \\
\text { amine }\end{array}$} \\
\hline & 30 & 60 & 30 & 60 & $30^{*}$ & $60^{*}$ & 30 & 60 & 30 & 60 & 30 & 60 & 30 & 60 & 30 & 60 & 30 & 60 \\
\hline CUB54 & 2 & 6 & 22 & 26 & I9 & 22 & 6 & 9 & 8 & 8 & 4 & 5 & 5 & 8 & 6 & 6 & 17 & 25 \\
\hline CUB76H & I 5 & I 6 & 52 & $4^{2}$ & 13 & 17 & 58 & 64 & $3 I$ & 34 & 15 & 17 & I 6 & 18 & 22 & 25 & 59 & 65 \\
\hline CUB296 & 0 & 0 & 0 & 0 & 3 & 4 & I & 3 & o & 0 & 0 & 0 & 0 & o & I & I & 21 & 37 \\
\hline CUB337 & 4 & 6 & 35 & 30 & I & I & 31 & 34 & 32 & 34 & 6 & 4 & 4 & 7 & 7 & 13 & I I & 24 \\
\hline CUB428 & 2 & 4 & 28 & 23 & 19 & 25 & $4 I$ & 45 & I 5 & I 8 & 6 & 6 & 7 & 7 & 4 & 4 & 18 & 32 \\
\hline CUB6I 5 & 19 & 20 & 48 & 30 & 23 & 26 & 43 & 46 & 38 & 39 & I 4 & 14 & Io & IO & 6 & 6 & 32 & 46 \\
\hline RI & I & 2 & 6 & 6 & 6 & 8 & 5 & 6 & 2 & 3 & I & I & I & 2 & 0 & 3 & 30 & 46 \\
\hline $\mathrm{H} 2$ & I & 2 & 39 & 36 & I & 1 & 49 & 52 & 3 & 4 & 2 & 2 & 2 & 2 & 3 & 3 & 19 & 27 \\
\hline $\mathrm{S} 2$ & 0 & 4 & 44 & 40 & 7 & 9 & 57 & 62 & 3 & 6 & 2 & 3 & I & 6 & I & 5 & 46 & 55 \\
\hline s3 & I & 2 & 15 & 12 & 22 & 20 & 27 & 32 & 14 & 18 & I & 2 & I & 2 & I & 2 & 9 & 17 \\
\hline
\end{tabular}

Figures in the 30 min column for half-strength nutrient broth are the lowest \% fall in o.D. recorded between 0 and $60 \mathrm{~min}$ in that system and are not necessarily the reading at $30 \mathrm{~min}$. This figure is given since some strains show rapid outgrowth in nutrient broth causing an increase in o.D. after the initial decrease accompanying germination.

* Heat-treated spore suspension used. 


\section{DISCUSSION}

The morphology of outgrowth in Micromonospora (Thermoactinomyces) iulgaris has been reported by Dorokhova, Agre, Kalakoutskii \& Krassilnikov (I968). Our results suggest that resemblances which exist between endospores of $T$. vulgaris and those of other bacteria (Cross et al. 1968; Dorokhova et al. 1968) can now be extended to include changes that occur during their germination. The change in $T$. vulgaris spores from phase-bright to phase-dark during germination, also recorded by Erikson (1955), is one such point of resemblance.

It is generally considered that integrity of integument structure is largely responsible for maintenance of dormancy and resistance in endospores (Gould \& Hitchens, I963; Lewis, I969). If this is so, then changes must take place in these layers early in germination to allow core development. The electron micrographs presented here illustrate a sequence of changes in the core until, in the germinated spore, its texture became similar to that of the vegetative organism and it was much enlarged. A number of changes also took place in the spore integuments which presumably facilitated core development and accommodated its expansion. Breakdown of intermediate and outer coats was only evident in the fully germinated spore, although irregularities of the inner coat were apparent earlier in germination. These irregularities may correspond to breaks in the inner coat of the germinated spore.

Hydrolysis of peptidoglycan in the cortex is an early germination event in spores of Bacillus species. This results in rapid uniform loss of the cortex by a lytic process in some species, e.g. Bacillus cereus (Hamilton \& Stubbs, 1967). Outgrowth in these species was found to be relatively insensitive to nisin (Gould \& Hurst, 1962). In other species, e.g. Bacillus subtilis, the electron-microscopic appearance of the cortex is hardly changed during germination, the integuments eventually splitting open to allow outgrowth of the organism. Outgrowth in these species is inhibited by nisin at 2 to Io $\mathrm{RU} / \mathrm{ml}$. In the Thermoactinomyces vulgaris strain examined here and in that studied by Dorokhova et al. (1968) the cortex does not appear to persist. In CUB337 it becomes uniformly degraded during germination in the same way as that of a lytic type Bacillus. But strain CUB337 differs from such bacilli in that degradation of its cortex is not completed early in germination and its outgrowth is inhibited by nisin.

Novobiocin, an antibiotic incorporated into a selective isolation medium for the endospore-producing species Thermoactinomyces vulgaris and Actinobifida dichotomica (Cross, 1968), did not inhibit outgrowth of strain CUB337 at $25 \mu \mathrm{g} / \mathrm{ml}$, but did inhibit Bacillus coagulans outgrowth at this concentration. It seems likely that this difference in sensitivity could explain the selectivity of the isolation medium for actinomycetes included in the genera Thermoactinomyces and Actinobifida.

Endospores of Thermoactinomyces vulgaris usually germinated in simple systems, e.g. buffer plus a single amino acid, like those of Bacillus species and unlike those of Clostridia which generally have more complex requirements. The response of $T$. vulgaris CUB337 to germinants, such as L-alanine, L-leucine, several other neutral amino acids, inosine and adenosine, was similar to certain Bacillus cereus strains. A further resemblance was the failure of sugars tested to initiate germination or potentiate the effect of $\mathrm{L}$-alanine. But other $T$. vulgaris strains examined did not conform to this response pattern. In strains such as CUB296 germination was negligible in most systems, whilst strains like CUB76 $\mathrm{H}$ germinated well. Strains with dormant endospores frustrate the study of physiology or biochemical reactions in the species and are probably at a selective disadvantage during isolation or subculture. Such dormant strains may respond to germinants under conditions other than those used in this study. Differences in germinative response between strains are also found in Bacillus 
species. Furthermore, these differences do not parallel established lines of classification (Thorley \& Wolf, I96I; Foerster \& Foster, I966; Sacks \& Thompson, I97I).

Bacterial endospores can often be 'heat activated', i.e. caused to germinate more rapidly by a prior heat treatment. However, the spores used here generally did not respond in this way. A comparison of results in Tables 2 and 3 show that in most instances 'ageing' enhanced the extent of germination achieved by a spore suspension, a phenomenon first described for Bacillus spp. by Powell (I950).

Erikson (I955) observed that germination of Micromonospora (Thermoactinomyces) vulgaris was not initiated by L-alanine or adenosine and suggested that this event differed in some fundamental way from that in eubacterial spores. Her failure to obtain germination with these two compounds may be accounted for by use of fresh (un-aged) spores, spores of unresponsive strains or use of unsuitable conditions, for example incubation at $60^{\circ} \mathrm{C}$.

The viable count of Thermoactinomyces sacchari, an organism closely related to $T$. vulgaris, was increased by incubation in L-alanine or calcium dipicolinate before plating out, or by incorporation of these compounds into the medium (Lacey, 1971). This suggests that $T$. sacchari endospores may also be germinated by agents found effective for eubacterial endospores.

The authors thank Mr G. J. Dring for help and advice and Mr J. M. Stubbs for the electron microscopy. This work was supported in part by a grant from the Science Research Council.

\section{REFERENCES}

Cross, T. (L968). Thermophilic actinomycetes. Journal of Applied Bacteriology 3r, 36-53.

CROSs, T. (1970). The diversity of bacterial spores. Journal of Applied Bacteriology 33, 95-102.

Cross, T., WALKeR, P. D. \& Gould, G. W. (1968). Thermophilic actinomycetes producing resistant endospores. Nature, London 220, 352-354.

Dorokhova, L. A., Agre, N. S., Kalakoutskit, L. V. \& Krassilnikov, N. A. (1968). Fine structure of spores in a thermophilic actinomycete, Micromonospora vulgaris. Journal of General and Applied Microbiology I4, 295-303.

ERIKSON, D. (1955). Changes in refractility and permeability accompanying germination of heat-resistant spores of Micromonospora vulgaris. Journal of General Microbiology 13, I 10-1 26.

FOERSTER, H. F. \& Foster, J. W. (I966). Response of Bacillus spores to combinations of germinative compounds. Journal of Bacteriology 9I, I $168-1177$.

Gould, G. W. \& Hitchins, A. D. (1963). Sensitization of bacterial spores to lysozyme and hydrogen peroxide with reagents which rupture disulphide bonds. Nature, London 197, 622.

Gould, G. W. \& HuRst, A. (1962). Inhibition of Bacillus spore development by nisin and subtilin. VIII International Congress for Microbiology, Montreal, Abstracts A2/II, p. I8. University of Toronto Press.

Gould, G. W. \& Hurst, A. (1969). The Bacterial Spore. London: Academic Press.

Gould, G. W., JONES, A. \& WRIGHTON, C. (1968). Limitations of the initiation of germination of bacterial spores as a spore control procedure. Journal of Applied Bacteriology 31, 357-366.

Hamilton, W. A. \& StubBs, J. M. (1967). Comparison of the germination and outgrowth of spores of Bacillus cereus and Bacillus polymyxa. Journal of General Microbiology 47, $12 \mathrm{I}-\mathrm{I} 29$.

Hopwood, D. A. \& Ferguson, H. M. (1970). Genetic recombination in a thermophilic actinomycete, Thermoactinomyces vulgaris. Journal of General Microbiology 63, 133-136.

LACEY, J. (I97I). Thermoactinomyces sacchari sp.nov., a thermophilic actinomycete causing bagassossis. Journal of General Microbiology 66, 327-338.

Lewis, J. C. (1969). Dormancy. In The Bacterial Spore, pp. 30 I-358. Edited by G. W. Gould and A. Hurst. London: Academic Press.

Mollenhauer, H. M. (1959). Permanganate fixation of plant cells. Journal of Biophysical and Biochemical Cytology 6, 43r. 
Powell, J. F. (1950). Factors affecting the germination of thick suspensions of Bacillus subtilis spores in L-alanine solution. Journal of General Microbiology 4, 330-338.

SAcks, L. E. \& Thompson, P. A. (197I). Germination requirements of Bacillus macerans spores. Journal of Bacteriology 105, 739-746.

Thorley, C. M. \& Wolf, J. (I96I). Some germination factors of mesophilic sporeformers. In Spores, vol. II, pp. I-I3. Edited by H. O. Halvorson. Minneapolis: Burgess Publishing Co. 